\title{
PENGARUH RASIO KEUANGAN TERHADAP KINERJA KEUANGAN PADA KOPERASI PRIMKOPAL LANAL TEGAL
}

\author{
Damar Kinasih*, Nurhadi Kamaludin
}

\begin{abstract}
Affiliation:
Accounting Department, Politeknik Muhammadiyah Tegal, Indonesia
\end{abstract}

\section{*Correspondence:}

damarkinasih3@gmail.com

Article Process:

Submitted:

December 21, 2021

Reviewed:

January 24, 2022

Revised:

January 31, 2022

Accepted:

February 2, 2022

Published:

February 15, 2022

\section{Citation:}

Kinasih. Damar, N. Kamaludin. (2022). Pengaruh Rasio Keuangan Terhadap Kinerja Keuangan Pada Koperasi Primkopal Lanal Tegal. RAAR: Review of Applied Accounting Research, 2 (1), 196-205.

Office Address:

Jl. K.H. Ahmad Dahlan, Dukuhwaluh, Kec. Kembaran, Kabupaten Banyumas, Jawa Tengah 53182

e-ISSN : 2807-8969

\begin{abstract}
ABSTRAK
Penelitian ini bertujuan untuk mengetahui pengaruh dari rasio likuiditas menggunakan current ratio, rasio solvabilitas menggunakan total debt to total asset, rasio rentabilitas menggunakan return on asset (ROA) secara parsial maupun simultan terhadap kinerja keuangan Koperasi Primkopal Lanal Tegal menggunakan sisa hasil usaha (SHU). Penelitian ini merupakan penelitian kuantitatif dengan menggunakan data sekunder berupa analisis rasio laporan keuangan bulanan pada Koperasi Primkopal Lanal Tegal dari tahun 2017 hingga tahun 2020. Penelitian ini menggunakan analisis regresi linier berganda untuk melihat pengaruh variabel independen yaitu Rasio Likuiditas (X1), Rasio Solvabilitas (X2) dan Rasio Rentabilitas (X3) terhadap Kinerja Keuangan yaitu menggunakan Sisa Hasil Usaha (Y). Hasil dari penelitian ini yaitu rasio likuiditas berpengaruh terhadap kinerja keuangan menggunakan Sisa Hasil Usaha, rasio solvabilitas berpengaruh negatif terhadap kinerja keuangan menggunakan Sisa Hasil Usaha, dan rasio rentabilitas berpengaruh positif terhadap kinerja keuangan menggunakan Sisa Hasil Usaha. Hasil dari rasio likuiditas, rasio solvabilitas, dan rasio rentabilitas secara simultan berpengaruh terhadap kinerja keuangan menggunakan Sisa Hasil Usaha dengan nilai koefisien determinasi sebesar 82,4\%.

Kata kunci: Rasio Likuiditas, Rasio Solvabilitas, Rasio Rentabilitas, Dan Sisa Hasil Usaha (SHU).
\end{abstract}

\section{ABSTRACT}

This research aims to find out the influence of liquidity ratio using current ratio, solvency ratio using total debt to total asset, rentability ratio using return on asset (ROA) partially and simultaneously to the financial performance of Lanal Tegal Primkopal Cooperative using the remaining business results (SHU). This study is a quantitative study using secondary data in the form of analysis of monthly financial statement ratios at Lanal Tegal Primkopal Cooperative from 2017 to 2020. This study used multiple linear regression analysis to look at the influence of independent variables namely Liquidity Ratio (X1), Solvency Ratio (X2) and Rentability Ratio (X3) to Financial Performance i.e. using Residual Business Results (Y). The results of this study are the ratio of liquidity affects financial performance using residual business results, solvency ratio negatively affects financial performance using residual business results, and rentability ratio positively affects financial performance using residual business results. The results of liquidity ratio, solvency ratio, and rentability ratio simultaneously affect financial performance using 
residual Business Results with coefficient of determination value of $82.4 \%$.

Keywords: Liquidity Ratio, Solvency Ratio, Profitability Ratio, and Remaining Operating Income (SHU).

\section{PENDAHULUAN}

Koperasi didirikan oleh sekelompok orang untuk memperjuangkan kesejahteraan ekonomi masyarakat. Koperasi menurut Undang-Undang Nomor 17 Tahun 2012, koperasi adalah badan hukum yang didirikan oleh orang perseorangan atau badan hukum koperasi, dengan pemisahan kekayaan para anggotanya sebagai modal untuk menjalankan usaha, yang memenuhi aspirasi dan kebutuhan bersama dibidang ekonomi, sosial, dan budaya sesuai dengan nilai dan prinsip koperasi. Tujuan koperasi menurut pasal 3 UU No.25 tahun 1992, yaitu koperasi bertujuan untuk mensejahterakan anggota serta ikut membangun perekonomian.

Untuk melihat keberhasilan suatu koperasi maka dibutuhkan pengukuran kinerja keuangan. Kinerja keuangan menurut Fahmi (2016: 2) adalah suatu analisis yang dilakukan untuk melihat sejauh mana suatu perusahaan telah melaksanakan dengan menggunakan aturan-aturan pelaksanaan keuangan secara baik dan benar. Mengukur kinerja keuangan dapat dilakukan dengan melihat pada laporan keuangan, salah satunya dengan melihat SHU yang dimiliki oleh suatu koperasi tersebut. Sisa Hasil Usaha (SHU) merupakan pendapatan selama satu tahun buku yang sudah dikurangi penyusutan, biaya dan pajak.

Koperasi Primkopal Lanal merupakan koperasi di lingkungan Angkatan Laut. Tugas pokok Primer Koperasi Angkatan Laut (Primkopal) adalah menyelenggarakan usaha perkoperasian diseluruh jajaran Angkatan Laut guna meningkatkan kesejahteraan anggota beserta keluarganya. Koperasi Primkopal Lanal mendirikan beberapa unit usaha, yaitu unit pertokoan dan unit simpan pinjam, dalam menjalankan usahanya Koperasi Primkopal Lanal menggunakan kekayaan yang dimiliki secara efektif dan efisien. Berikut ini tabel posisi keuangan yang terdiri dari Sisa Hasil Usaha (SHU), rasio likuiditas menggunakan current ratio, rasio solvabilitas menggunakan debt to total asset dan rasio rentabilitas menggunakan return on asset dari laporan keuangan tahunan pada tahun 2017 hingga tahun 2020:

Tabel 1. Posisi Keuangan

\begin{tabular}{|c|c|c|c|c|}
\hline Tahun & Sisa Hasil Usaha (SHU) & Current ratio \% & Debt to total asset \% & Return on asset \% \\
\hline 2017 & Rp. $111.240 .569,78$ & 189,29 & 50,55 & 8,78 \\
\hline 2018 & Rp. $98.983 .572,97$ & 248,22 & 37,99 & 8,73 \\
\hline 2019 & Rp. 79.256.153,64 & 222,49 & 41,83 & 5,69 \\
\hline 2020 & Rp. $100.788 .436,65$ & 278,58 & 32,59 & 7,49 \\
\hline
\end{tabular}

Sumber : Data Diolah, 2021

Dari hasil tabel diatas nilai Sisa Hasil Usaha (SHU) yang didapat Koperasi sangat tidak stabil karena mengalami penurunan dari tahun 2017 hingga tahun 2019 dan kembali naik pada tahun 2020. Nilai current ratio yang diperoleh juga naik turun setiap tahunnya yaitu naik pada tahun 2018 lalu turun dan kembali naik lagi pada tahun 2020. Nilai debt to total asset juga sama seperti nilai current ratio yaitu mengalami penurunan pada tahun 2018, kenaikan pada tahun 2019 dan kembali turun pada tahun 2020. Nilai return on

RAAR

Vol.2 No.1 
asset disini mengalami penurunan dari tahun 2017 hingga tahun 2019 dan mengalami kenaikan pada tahun 2020 seperti nilai Sisa Hasil Usaha (SHU) pada Koperasi Primkopal Lanal Tegal.

Hasil penelitian terdahulu Agnes Susana Merry Purwati (2019) menunjukkan bahwa rasio likuiditas menggunakan current ratio berpengaruh positif terhadap sisa hasil usaha (SHU) dan menurut Muhammad Fauzi (2017), I Wayan Tegar Baskara, dkk (2020), Isna Farah Albana (2015) menunjukkan bahwa rasio likuiditas menggunakan current ratio tidak berpengaruh terhadap sisa hasil usaha (SHU).

Penelitian yang dilakukan oleh Muhammad Fauzi (2017) menunjukkan bahwa rasio solvabilitas menggunakan debt to total asset berpengaruh positif terhadap kinerja keuangan, dan menurut Isma Octavia Ade Fufani (2013) menunjukkan bahwa rasio solvabilitas menggunakan debt to total asset berpengaruh negatif terhadap sisa hasil usaha (SHU).

Penelitian yang dilakukan oleh Muhammad Fauzi (2017) menunjukkan bahwa rasio rentabilitas menggunakan return on asset berpengaruh terhadap kinerja keuangan, dan menurut I Wayan Tegar Baskara, dkk (2020) menunjukkan bahwa rasio rentabilitas menggunakan return on asset tidak berpengaruh terhadap sisa hasil usaha (SHU).

Berdasarkan latar belakang masalah diatas maka tujuan dari penelitian ini adalah: (1) untuk mengetahui bagaimana pengaruh rasio likuiditas terhadap kinerja keuangan Koperasi Primkopal Lanal Tegal, (2) untuk mengetahui bagaimana pengaruh rasio solvabilitas terhadap kinerja keuangan Koperasi Primkopal Lanal Tegal, (3) untuk mengetahui bagaimana pengaruh rasio rentabilitas terhadap kinerja keuangan Koperasi Primkopal Lanal Tegal, (4) untuk mengetahui bagaimana pengaruh rasio likuiditas, rasio solvabilitas dan rasio rentabilitas terhadap kinerja keuangan Koperasi Primkopal Lanal Tegal.

\section{TINJAUAN PUSTAKA}

\section{Rasio Likuiditas}

Menurut Kasmir (2014:129), Likuiditas (liquidity ratio) merupakan rasio yang menggambarkan atau mengukur kemampuan perusahaan dalam memenuhi kewajiban (utang) jangka pendek. Artinya apabila perusahaan ditagih, perusahaan akan mampu untuk memenuhi utang tersebut terutama utang yang sudah jatuh tempo."

Current ratio adalah rasio yang digunakan untuk mengukur kemampuan perusahaan membayar kewajiban atau hutang jangka pendek yang akan jatuh tempo pada saat ditagih secara keseluruhan (Kasmir, 2014:134).

Dari pengertian diatas rasio likuiditas menggunakan current ratio yaitu sejauh mana aktiva lancar dapat memenuhi kewajiban lancar atau kewajiban jangka pendeknya. Semakin besar rasio likuiditas maka akan mempengaruhi kinerja keuangan menggunakan sisa hasil usaha (SHU) dan menunjukkan bahwa koperasi mampu menutupi kewajiban lancar. Namun, jika rasio likuiditas terlalu tinggi juga tidak baik Vol.2 No.1 yaitu artinya menunjukkan koperasi tidak menggunakan aktiva dengan efektif dan efisien. 


\section{Rasio Solvabilitas}

Menurut Kasmir (2014:153), leverage adalah Rasio solvabilitas atau leverage ratio merupakan rasio yang digunakan dalam mengukur sejauh mana aktifitas perusahaan dibiayai dengan utang.

Debt to total asset merupakan rasio utang yang digunakan untuk mengukur perbandingan antara total utang dengan total aktiva. Dengan kata lain, seberapa besar aktiva perusahaan dibiayai oleh utang atau seberapa besar utang perusahaan berpengaruh terhadap pengelolaan aktiva (Kasmir, 2014:156).

Dari pengertian diatas rasio solvabilitas menggunakan debt to total asset yaitu sejauh mana aktiva dibiayai oleh hutang. Semakin kecil rasio solvabilitas maka akan mempengaruhi kinerja keuangan menggunakan sisa hasil usaha (SHU) dan menunjukkan bahwa aktiva yang dibiayai oleh hutang tidak banyak, sehingga mengurangi beban yang timbul dari hutang .

\section{Rasio Rentabilitas}

Menurut Kasmir (2014:196), rentabilitas merupakan rasio untuk menilai kemampuan perusahaan dalam mencari keuntungan. Rasio ini juga memberikan ukuran tingkat efektivitas manajemen suatu perusahaan. Hal ini ditunjukkan oleh laba yang dihasilkan dari penjualan dan pendapatan investasi.

Return on assets (ROA) merupakan rasio yang menunjukan hasil (return) atas jumlah aktiva yang digunakan dalam perusahaan atas suatu ukuran tentang aktivitas manajemen (Kasmir, 2014:201).

Dari pengertian diatas rasio rentabilitas menggunakan return on asset yaitu sejauh mana koperasi mampu menghasilkan laba dari aktiva yang dimiliki. Semakin besar rasio rentabilitas maka akan mempengaruhi kinerja keuangan menggunakan sisa hasil usaha (SHU) dan menunjukkan bahwa koperasi menggunakan aktiva sebagai modal untuk mendapatkan laba dengan efektif dan efisien.

\section{Kinerja Keuangan}

Menurut Indriyo dan Basri (2002: 275), konsep kinerja keuangan yaitu rangkaian aktivitas keuangan pada suatu periode tertentu yang dilaporkan dalam laporan keuangan diantaranya laporan laba rugi dan neraca. Menurut Fahmi (2016: 2), kinerja keuangan adalah suatu analisis yang dilakukan untuk melihat sejauh mana suatu perusahaan telah melaksanakan dengan menggunakan aturan-aturan pelaksanaan keuangan secara baik dan benar.

Salah satu pengukuran kinerja bisa dilihat dari Sisa Hasil Usaha (SHU). Berdasarkan UU No. 25 Tahun 1992 tentang koperasi pasal 45 ayat 2 bahwa, sisa hasil usaha setelah dikurangi dana cadangan, dibagikan kepada anggota sebanding dengan jasa usaha yang dilakukan oleh masing-masing anggota dengan koperasi, serta digunakan untuk keperluan pendidikan perkoperasian dan keperluan lain dari koperasi, sesuai dengan keputusan rapat anggota.

\section{HIPOTESIS PENELITIAN}


H0 1 : Likuiditas tidak berpengaruh terhadap kinerja keuangan.

Ha 1 : Likuiditas berpengaruh terhadap kinerja keuangan.

H0 2 : Solvabilitas tidak berpengaruh terhadap kinerja keuangan.

Ha 2 : Solvabilitas berpengaruh terhadap kinerja keuangan.

H0 3 : Rentabilitas tidak berpengaruh terhadap kinerja keuangan.

Ha 3 : Rentabilitas berpengaruh terhadap kinerja keuangan.

H0 4 : Rasio Likuiditas, Rasio Solvabilitas, dan Rasio Rentabilitas tidak berpengaruh terhadap kinerja keuangan.

Ha 4 :Rasio Likuiditas, Rasio Solvabilitas, dan Rasio Rentabilitas berpengaruh terhadap kinerja keuangan.

\section{METODOLOGI PENELITIAN}

Pada penelitian ini menggunakan penelitian kuantitatif, dengan sumber data berupa laporan keuangan bulanan pada Koperasi Primkopal Lanal Tegal dari tahun 2017 sampai dengan tahun 2020. Populasi dalam penelitian ini adalah laporan keuangan pada Koperasi Primkopal Lanal Tegal dan sampel yang digunakan pada penelitian ini yaitu analisis laporan keuangan bulanan dari tahun 2017 hingga tahun 2020 dengan total sampel ada 48 bulan.

Instrument yang digunakan dalam penelitian ini yaitu ada 2 variabel yaitu variabel bebas dan variabel terikat. Variabel bebas dalam penelitian ini adalah Rasio Likuiditas (X1), Rasio Solvabilitas (X2) dan Dan Rasio Rentabilitas (X3), untuk variabel terikatnya adalah Kinerja keuangan menggunakan Sisa Hasil Usaha (SHU) (Y).

Teknik analisis data dalam penelitian ini yaitu

\section{Uji Asumsi Klasik}

Uji normalitas data menggunakan uji Kolmogorov-smirnov dengan pengambilan keputusan probabilitas $>0,05$, maka data berdistribusi normal.

Uji multikolinieritas dengan melihat nilai tolerance $>0,10$ dan nilai VIF yaitu $<10$, maka data tidak terjadi multikolinieritas.

Uji heterokedastisitas dengan melihat pola gambar scatterplots, jika data tersebar dibawah, disekitar, dan diatas angka nol maka data tidak terjadi heterokedastisitas.

\section{Analisis Regresi Linier Berganda}

Regresi linier berganda menggunakan dua atau lebih variabel bebas yang dimasukkan dalam model regresi (Priyatno, 2013: 130).

Berikut persamaan umum regresi linier berganda :

\section{RAAR}

$$
Y=a+b 1 X 1+b 2 \times 2+b 3 \times 3+e
$$

Vol.2 No.1

$$
\begin{array}{ll}
\mathrm{Y} & =\text { Kinerja Keuangan } \\
\mathrm{a} & =\text { Konstanta } \\
\mathrm{b} & =\text { Koefisien Variabel } \mathrm{X} \\
\mathrm{X} 1 & =\text { Rasio Likuiditas }
\end{array}
$$


$\mathrm{X} 2=$ Rasio Solvabilitas

$\mathrm{X} 3$ = Rasio Rentabilitas

$\mathrm{e} \quad=$ Error Term

\section{Pengujian Hipotesis}

\section{Uji- $t$ (Uji Parsial)}

Pengambilan keputusan data melalui program SPSS 2.2 sebagai berikut:

$\mathrm{HO}=$ Variabel independen secara parsial tidak berpengaruh terhadap variabel dependen.

$\mathrm{Ha}=$ Variabel independen secara parsial berpengaruh terhadap variabel dependen.

Dasar pengambilan keputusan pengujian dengan uji $t$ yaitu dengan taraf signifikansi $5 \%$ atau 0,5. Jika taraf signifikansi kurang dari 0,5, maka variabel dindependen berpengaruh terhadap variabel dependen secara parsial.

\section{Uji-F (Uji Simultan)}

Pengambilan keputusan data melalui program SPSS 2.2 sebagai berikut:

$\mathrm{HO}=$ Variabel independen secara simultan tidak berpengaruh terhadap variabel dependen.

$\mathrm{Ha}=$ Variabel independen secara simultan berpengaruh terhadap variabel dependen.

Dasar pengambilan keputusan pengujian dengan uji $\mathrm{F}$ ini membandingkan nilai $\mathrm{F}$ hitung dengan $\mathrm{F}$ tabel pada $\alpha=0,05$, hasil perhitungan akan menunjukkan:

1) Jika $\mathrm{F}$ hitung < F tabel atau tingkat signifikansi > 0,05 maka H0 diterima. Artinya variabel independent tidak dapat digunakan sebagai penduga yang dipercaya untuk memprediksi pengaruh variabel independen terhadap variabel dependent.

2) Jika $\mathrm{F}$ hitung $>\mathrm{F}$ tabel atau tingkat signifikansi $<0,05$ maka $\mathrm{H} 0$ ditolak. Artinya bahwa variabel independent dapat digunakan sebagai penduga yang dipercaya untuk memprediksi pengaruh variabel independent terhadap variabel dependent.

\section{Uji Koefisien Determinasi (R Square).}

Menurut Ghozali (2011: 97), apabila dalam uji empiris didapat nilai Adjusted $\mathrm{R}^{2}$ negatif maka nilai Adjusted $\mathrm{R}^{2}$ dianggap bernilai 0 .

\section{HASIL DAN PEMBAHASAN}

\section{Uji Asumsi Klasik}

1) Uji Normalitas

Uji normalitas menggunakan Uji Kolmogorov-Smirnov diperoleh nilai Asymp. Sig. (2-tailed) sebesar 0,055 lebih besar dari 0,05. Artinya data yang digunakan dalam penelitian ini memiliki model regresi berdistribusi normal.

2) Uji Multikolinieritas

RAAR

Vol.2 No.1 
Dalam uji multikolinieritas diperoleh koefisien nilai Tolerance lebih besar dari 0,10 dan nilai VIF lebih kecil dari 10,00. Maka dalam data penelitian ini tidak terjadi multikolinieritas.

3) Uji Heterokedastisitas

Dalam uji heterokedastisitas melihat pada gambar scatterplot yaitu tidak terjadi heterokedastisitas sehingga penelitian ini memiliki model regresi berdistribusi normal yaitu titik-titik menyebar diatas, dibawah dan disekitar angka nol.

\section{Uji Regresi Linier Berganda}

Regresi linier berganda bertujuan untuk mengetahui pengaruh dua atau lebih variabel bebas terhadap variabel terikat. Berikut persamaan umum regresi linier berganda :

$Y=a+b 1 X 1+b 2 \times 2+b 3 X 3+e$

Tabel 1. Analisis Regresi Linier Berganda

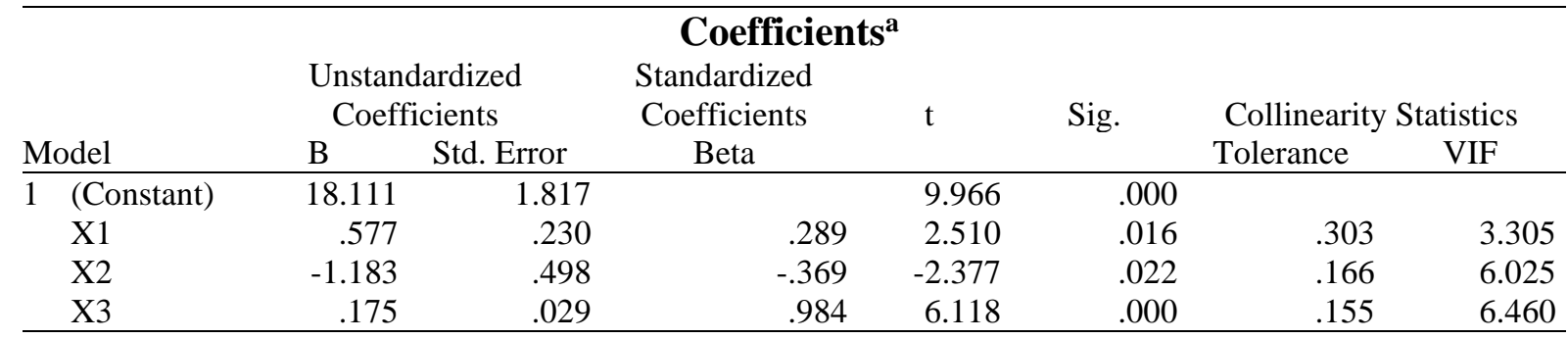

Sumber: Output SPSS (2021)

Dari tabel diatas, persamaan regresi linier berganda dapat disusun sebagai berikut :

$\mathrm{Y}=18.111+0,577 \mathrm{X} 1-1,183 \mathrm{X} 2+0,175 X 3+\mathrm{e}$

\section{Pengujian Hipotesis}

1) Uji- $t$ (Uji Parsial)

Dapat dilihat pada tabel .. yaitu X1 atau Rasio Likuiditas memiliki nilai signifikansi sebesar 0.016 lebih kecil dari 0,05 dan nilai t hitung sebesar 2.510, maka H0 ditolak dan Ha diterima. Hal ini menunjukkan rasio likuiditas berpengaruh positif terhadap kinerja keuangan menggunakan sisa hasil usaha (SHU).

X2 atau Rasio Solvabilitas memiliki nilai signifikansi sebesar 0.022 lebih kecil dari 0,05 dan nilai t hitung sebesar -2.377, maka H0 ditolak dan Ha diterima. Hal ini menunjukkan rasio solvabilitas berpengaruh negatif terhadap kinerja keuangan menggunakan sisa hasil usaha (SHU).

RAAR X3 atau Rasio Rentabilitas memiliki nilai signifikansi sebesar 0.000 lebih kecil dari Vol.2 No.1 0,05 dan nilai t hitung sebesar 6.118, maka H0 ditolak dan Ha diterima. Hal ini menunjukkan rasio rentabilitas berpengaruh positif terhadap kinerja keuangan menggunakan sisa hasil usaha (SHU).

2) Uji-F (Uji Simultan) 
Dari perhitungan yang dibantu program SPSS 2.2 diperoleh hasil sebagai berikut

Tabel 2. Uji-F (Uji Simultan)

\begin{tabular}{|c|c|c|c|c|c|c|}
\hline \multicolumn{7}{|c|}{ ANOVAa } \\
\hline Mode & & Sum of Squares & df & Mean Square & & \\
\hline \multirow[t]{3}{*}{1} & Regression & 9.582 & 3 & 3.194 & 68.603 & $.000^{\mathrm{b}}$ \\
\hline & Residual & 2.049 & 44 & .047 & & \\
\hline & Total & 11.631 & 47 & & & \\
\hline
\end{tabular}

Sumber: Output SPSS (2021)

Berdasarkan hasil uji $\mathrm{F}$ rasio likuiditas, solvabilitas, dan rentabilitas bahwa hasil $\mathrm{F}$ hitung bernilai sebesar 68.603 dan $\mathrm{F}$ tabel 2,82 yang berarti $\mathrm{F}$ hitung lebih besar dari $\mathrm{F}$ tabel dengan probabilitas Sig. 0,000 < 0,05, maka H0 ditolak dan Ha diterima. Hal ini menunjukkan rasio likuiditas, rasio solvabilitas, dan rasio rentabilitas secara simultan berpengaruh terhadap kinerja keuangan menggunakan sisa hasil usaha (SHU).

\section{Uji Koefisien Determinasi $\mathbf{R}^{2}(R$ Square $)$}

Uji determinasi untuk mengetahui seberapa besar prediksi pengaruh yang diberikan variabel independent secara simultan terhadap variabel dependen.

Tabel 3. Uji Determinasi $\mathrm{R}^{2}$ ( $R$ Square)

\begin{tabular}{lcccr}
\hline \multicolumn{4}{c}{ Model Summary $^{\mathbf{b}}$} \\
Model & $\mathrm{R}$ & $\mathrm{R}$ Square & $\begin{array}{c}\text { Adjusted R } \\
\text { Square }\end{array}$ & $\begin{array}{l}\text { Std. Error of } \\
\text { the Estimate }\end{array}$ \\
1 & $.908^{\mathrm{a}}$ & .824 & .812 & .21578 \\
\hline Sumber: Output SPSS (2021) & & &
\end{tabular}

Berdasarkan tabel diatas, dapat diketahui bahwa nilai koefisien determinasinya adalah sebesar 0.824 hal ini berarti bahwa rasio likuiditas, solvabilitas dan rentabilitas berpengaruh secara simultan sebesar $82,4 \%$ sisanya $27,6 \%$ dipengaruhi oleh faktor lain.

\section{Pembahasan}

Berdasarkan hasil analisis regresi untuk rasio likuiditas menunjukkan bahwa nilai signifikansi sebesar 0.016 lebih kecil dari 0,05 dan nilai t hitung sebesar 2.510, maka H0 ditolak dan Ha diterima. Hal ini menunjukkan rasio likuiditas berpengaruh positif terhadap kinerja keuangan yaitu menggunakan sisa hasil usaha (SHU) pada Koperasi Primkopal Lanal Tegal diterima. Hubungan pengaruh rasio likuiditas terhadap kinerja keuangan positif, yang artinya rasio likuiditas mempunyai hubungan searah dengan kinerja keuangan menggunakan sisa hasil usaha (SHU). Rasio likuiditas memiliki nilai koefisien beta sebesar 0,577. Hal ini menunjukkan bahwa setiap kenaikan likuiditas satu satuan maka kinerja keuangan menggunakan sisa hasil usaha (SHU) akan naik sebesar 0,577 , begitu juga sebaliknya pada penurunan likuiditas. Pernyataan diatas sejalan dengan penelitian yang dilakukan oleh Agnes Susana Merry Purwati (2019), yang menyebutkan rasio likuiditas dengan pengukuran menggunakan current ratio berpengaruh terhadap sisa hasil usaha (SHU).

Rasio solvabilitas menunjukkan bahwa nilai signifikansi sebesar 0.022 lebih kecil dari 
menunjukkan rasio solvabilitas berpengaruh negatif terhadap kinerja keuangan menggunakan sisa hasil usaha (SHU) pada Koperasi Primkopal Lanal Tegal diterima. Namun hubungan pengaruh rasio solvabilitas terhadap kinerja keuangan negatif, yang artinya rasio solvabilitas mempunyai hubungan berlawan arah dengan kinerja keuangan menggunakan sisa hasil usaha (SHU). Rasio solvabilitas memiliki nilai koefisien beta sebesar - 1,183. Hal ini menunjukkan bahwa setiap kenaikan solvabilitas satu satuan maka kinerja keuangan menggunakan sisa hasil usaha (SHU) akan turun sebesar 1,183, begitu juga sebaliknya pada penurunan solvabilitas. Pernyataan diatas sejalan dengan penelitian yang dilakukan oleh Isma Octavia Ade Fufani (2013), yang menyebutkan rasio solvabilitas dengan pengukuran menggunakan debt to total asset berpengaruh negatif terhadap sisa hasil usaha (SHU).

Rasio rentabilitas menunjukkan bahwa signifikansi sebesar 0.000 lebih kecil dari 0,05 dan nilai t hitung sebesar 6.118, maka $\mathrm{HO}$ ditolak dan Ha diterima. Hal ini menunjukkan rasio rentabilitas berpengaruh terhadap kinerja keuangan menggunakan sisa hasil usaha (SHU) pada Koperasi Primkopal Lanal Tegal diterima. Rasio rentabilitas memiliki nilai koefisien beta sebesar 0,175 , artinya rentabilitas mempunyai hubungan searah dengan kinerja keuangan. Hal ini menunjukkan bahwa setiap kenaikan rentabilitas satu satuan maka kinerja keuangan akan naik sebesar 0,175 , begitu juga sebaliknya pada penurunan rentabilitas. Pernyataan diatas ini sejalan dengan penelitian yang dilakukan oleh Muhammad Fauzi (2017), yang menyebutkan rasio rentabilitas dengan pengukuran menggunakan return on asset berpengaruh positif terhadap sisa hasil usaha (SHU).

Berdasarkan hasil uji $\mathrm{F}$ rasio likuiditas, solvabilitas, dan rentabilitas memiliki nilai $\mathrm{F}$ hitung sebesar 68.603 lebih besar dari $F$ tabel yaitu 2,81 dan nilai signifikansi 0,000 lebih kecil dari 0,05. Maka hipotesis bahwa rasio likuiditas, solvabilitas dan rentabilitas berpengaruh terhadap kinerja keuangan menggunakan sisa hasil usaha (SHU) pada Koperasi Primkopal Lanal Tegal diterima. Nilai koefisien determinasi $\left(\mathrm{R}^{2}\right)$ pada penelitian ini yaitu sebesar 0.824 hal ini berarti bahwa rasio likuiditas, solvabilitas dan rentabilitas berpengaruh secara simultan sebesar $82,4 \%$ sisanya $27,6 \%$ dipengaruhi oleh faktor lain.

\section{SIMPULAN DAN SARAN}

Berdasarkan hasil penelitian yang dilakukan pada Koperasi Primkopal Lanal Tegal dengan mengolah sampel laporan keuangan dengan menganalisis laporan keuangan bulanan dari tahun 2017 hingga tahun 2020 dengan menggunakan SPSS Versi 22.0 maka dapat disimpulkan bahwa :

1. Rasio likuiditas berpengaruh terhadap kinerja keuangan menggunakan sisa hasil usaha (SHU) pada Koperasi Primkopal Lanal Tegal. Maka hipotesis bahwa rasio likuiditas berpengaruh signifikan terhadap kinerja keuangan pada Koperasi Primkopal Lanal Tegal diterima.

2. Rasio solvabilitas berpengaruh negatif terhadap kinerja keuangan menggunakan sisa hasil usaha (SHU) pada Koperasi Primkopal Lanal Tegal. Maka hipotesis bahwa rasio solvabilitas berpengaruh signifikan terhadap kinerja keuangan pada Koperasi Primkopal Lanal Tegal diterima.

Vol.2 No.1 3. Rasio rentabilitas secara parsial berpengaruh kinerja keuangan menggunakan sisa hasil usaha (SHU) pada Koperasi Primkopal Lanal Tegal. Maka hipotesis bahwa rasio 
rentabilitas berpengaruh signifikan terhadap kinerja keuangan pada Koperasi Primkopal Lanal Tegal diterima.

4. Rasio likuiditas, solvabilitas dan rentabilitas secara simultan kinerja keuangan menggunakan sisa hasil usaha (SHU) pada Koperasi Primkopal Lanal Tegal. Maka hipotesis bahwa rasio likuiditas, solvabilitas dan rentabilitas secara simultan berpengaruh signifikan terhadap kinerja keuangan pada Koperasi Primkopal Lanal Tegal diterima.

\section{REFERENSI}

Albana, Isna Farah. 2015. Pengaruh Modal Sendiri Dan Current Ratio Terhadap Sisa Hasil Usaha (Shu) Di Kpri Kota Semarang Tahun 2013. Skripsi. Semarang: Universitas Negeri Semarang.

Baskara, I Wayan Tegar dkk. 2020. Pengaruh Rasio Likuiditas, Rasio Profitabilitas, Dan Aktiva Produktif Terhadap Pertumbuhan Sisa Hasil Usaha Koperasi Simpan Pinjam Di Kecamatan Sukawati. Dalam Jurnal Widya Manajemen (Hlm 43-54). Denpasar: Universitas Mahasaraswati Denpasar.

Fahmi, Irham. 2016. Pengantar Manajemen Keuangan. Bandung : Alfabeta, CV.

Fauzi, Muhammad. 2017. Pengaruh Rasio Likuiditas, Solvabilitas dan Rentabilitas Terhadap Kinerja Keuangan Kopontren Al Hidayaat Kec Pringapus Kab Semarang Tahun 2009-201. Skripsi. Semarang: Universitas Islam Negeri Walisongo Semarang.

Fufani, Isma Octavia Ade. 2013. Pengaruh Struktur Modal Terhadap Sisa Hasil Usaha (Shu) Pada Koperasi Pegawai Republik Indonesia (Kpri) Se Kota Semarang. Skripsi. Semarang: Universitas Negeri Semarang.

Ghozali, Imam. 2011. Aplikasi Analisis Multivariate Dengan Program SPSS. Semarang: Badan Penerbit Universitas Diponegoro

Gitosudarmo, Indriyo dan Basri. 2002. Manajemen Keuangan. Yogyakarta: BPFE.

Kasmir. 2014. Analisis Laporan Keuangan. Edisi Pertama. Cetakan Ketujuh. Jakarta: PT. Rajagrafindo Persada.

Priyatno, Duwi. 2013. Mandiri Belajar Analisis Data Dengan SPSS.Mediakom.

Purwati, Agnes Susana Merry. 2019. Analisis Rasio Keuangan Terhadap Pembagian Sisa Hasil Usaha Pada Koperasi Kredit Anugerah Bandarjaya Lampung Tengah. Dalam Gema. Lampung: Sekolah Tinggi Ilmu Ekonomi Gentiaras Lampung.

Republik Indonesia. 1992. Undang-Undang Republik Indonesia Nomor 25 Tahun 1992 Tentang Perkoprasian. Jakarta : Sekretariat Negara.

Undang - Undang Republik Indonesia No. 17 Tahun 2012 tentang Perkoperasian. 